\title{
JURNAL PENGABDIAN PADA MASYARAKAT
}

\section{Aplikasi Teknologi Budidaya Buah Naga untuk Daerah Pesisir di Kelurahan Kalijaga, Kecamatan Harjamukti, Kota Cirebon}

\author{
Sudarjat ${ }^{1}$, Erni Suminar², Muhamad Abdilah HasanQanit ${ }^{3}$, Syariful Mubarok ${ }^{4}$ \\ 1, 2, 3, 4 Universitas Padjadjaran
}

\begin{tabular}{l}
\hline Article History \\
\hline Received 09.10 .2018 \\
Received in revised form \\
20.03 .2019 \\
Accepted 01.04 .2019 \\
Available online 26.04 .2019
\end{tabular}

\begin{abstract}
APPLICATION OF DRAGON FRUIT CULTIVATION TECHNOLOGY FOR COASTAL AREAS IN KALIJAGA VILLAGE, HARJAMUKTI DISTRICT, CIREBON CITY. Dragon fruit is one of the growing fruit commodities and is widely known in Indonesia. The distribution process has reached all of Indonesia. The development of dragon fruit in West Java itself is still said to be low, so it is necessary to increase or open a new area for the cultivation process which directly helps in terms of land and water conservation. In West Java alone, one location that has the potential to become a dragon fruit cultivation area is the City of Cirebon. Cirebon City is a strategic city that connects West Java and Central Java. However, the condition of the land in Cirebon is mostly unproductive. So it is necessary to find ways to increase the productivity of the land, namely through the application of technology to cultivate dragon fruit plants in coastal areas. To increase public awareness to reproduce agricultural land in the area, one of them is the process of mentoring the introduction of suitable types of plants grown in the area and appropriate cultivation technology for the area. The area that will be used as partners for this activity is Kalijaga Village, Kec. Harjamukti by involving two farmer groups, Sekar Maju, and Sidemung. The method that will be carried out in this assistance is the process of counseling, practice and making demonstration plots of dragon fruit planting that can be used as a learning tool in the area. From the results of the counseling, it was seen that the community's enthusiasm was high to want to know more about dragon fruit and how to cultivate dragon fruit in the area, so that dragon fruit in the area could develop.
\end{abstract}

Keywords: Cirebon, Community, Cultivation, Dragon fruit. Attribution 4.0 International License, which permits unrestricted use, distribution, and reproduction in any medium, provided the original work is properly cited. ○ 2019 Sudarjat, Erni Suminar, Muhamad Abdilah HasanQanit, Syariful Mubarok. 


\section{PENDAHULUAN}

Kota Cirebon merupakan daerah dataran rendah dengan ketinggian tempat $\pm 5 \mathrm{~m}$ di atas permukaan laut dan berada di utara Provinsi Jawa Barat. Luas wilayah kota Cirebon adalah $37,54 \mathrm{~km}^{2}$ dengan dominasi penggunaan lahan untuk perumahan $(32 \%)$ dan tanah pertanian $(38 \%)$. Cirebon merupakan kabupaten yang mengalami perkembangan ekonomi yang tinggi karena kota Cirebon berada pada lokasi yang Perkembangan sektor pertanian di Cirebon sudah dikatakan maju untuk komoditas padi dan palawija. Namun ada beberapa areal yang belum digunakan makasimal sehingga daya guna lahan semakin rendah.

Kelompok Tani Sekar Maju dan Sidemang merupakan dua kelompok tani yang berada di Kelurahan Kalijaga, Kec. Harjamukti, Kota Cirebon. Kedua kelompok tani ini berada pada kelurahan yang persentasi penduduknya mempunyai tingkat kemiskinan nomor dua di kecamatan Harjamukti. Dengan demikian, untuk meningkatkan taraf hidup penduduk di kelurahan ini dapat dilakukan salah satunya adalah dengan pemberdayaan penduduk dan juga kedua kelompok tadi tersebut untuk meningkatkan sektor pertanian. Sektor pertanian di kelurahan Harjamukti dapat dikatakan masih kurang berkembang salah satunya kurang aktifnya masyarakat ataupun kelompok tani dalam melakukan pemberdayaan lahan. Selain itu penurunan sektor pertanian di kelurahan ini salah satunya adalah diakibatkan karena banyaknya lahan yang kurang produktif diakibatkan lahan yang berada di Cirebon mempunya tingkat salinitas tinggi karena berada pada pesisir pantai. Tingginya salinitas tanah dan suhu yang tinggi sehingga hanya sedikit tanaman yang dapat tumbuh dan berproduksi dengan baik. Salah satu cara yang dapat digunakan adalah memilih jenis tanaman dan cara budidaya yang baik sehingga tanaman tersebut dapat tumbuh, berkembang dan berproduksi dengan baik. Melihat lokasi kecamatan Harjamukti berada pada lokasi yang strategis di dekat pantai dan pusat kota Cirebon, sehingga pemberdayaan kelompok tani yang didasarkan pada pemanfaatan potensi daerah, salah satunya dengan peningkatan produkstivitas sektor pertanian untuk mendukung sektor pariwisata.

Pemilihan jenis tanaman dan teknologi budidaya yang dapat dikembangkan di lahan kurang produktif dan mempunyai suhu lingkungan tinggi salah satunya adalah dengan pengembangan budidaya buah naga yang dapat dijadikan sebagai salah satu tujuan objek wisata buah naga di daerah pesisir. Dalam pemanfaatan lahan kurang produktif untuk budidaya buah naga ini, masyarakat belum banyak mengetahui bagaimana teknologi pemanfaatan daya alih lahan dari areal pesisir menjadi areal pertanian. Sehingga untuk meningkatkan pemahaman masyarakat untuk mengetahui dengan baik bagaimana teknologi budidaya ini dapat diaplikasikan harus dilakukan pendampingan secara menyeluruh baik dari segi perbanyakan dan budidaya tanamannya.

Ketertarikan masyarakat di Kelurahan Kalijaga, Kecamatan Harjamukti Kota Cirebon akan buah naga terlihat sangat tinggi. Mereka hanya mengenal beberpa jenis buah naga yang salah satunya adalah buah naga spesies Hylocereus undatus. Buah naga ini merupakan salah satu jenis yang sudah banyak dikembangkan di Indonesia (Kristanto, 2010). Permintaan buah naga meningkat setiap tahunnya baik di pasar domestic maupun pasar internasional. Pada saat ini, harga buah naga cukup tinggi, berkisar antara Rp 10.000 s.d. Rp. 23.000 ditingkat produsen dan Rp 25.000 s.d. Rp 30.000 ditingkat konsumen, sehingga sangat besar pengaruhnya terhadap perluasan komoditas buah naga di Indonesia. Buah naga di pasar ekspor jumlahnya masih sedikit, karena buah ini belum banyak dikenal di banyak negara. Sehingga buah ini mempunyai prospek yang baik 
untuk dikembangkan (Chusna, 2011; Kristriandiny \& Susanto, 2017). Melihat permintaan akan buah naga terus meningkat maka perlu adanya peningkatan produksi buah naga di Indonesia, yang salah satunya adalah dengan pengembangan dan pencarian lokasi penanaman yang cocok untuk pertumbuhan buah naga di Indonesia.

Berdasarkan habitat aslinya yang berasal dari daerah tropis, pengembangan dan penanaman buah naga di Indonesia mempunyai prospek dan peluang yang baik. Daerah yang dapat dikembangkan untuk budidaya dan pengembangan buah naga adalah daerah yang mempunyai suhu tinggi yang cocok untuk pertumbuhan dan perkembangan tanaman buah naga yang salah satunya adalah Kota Cirebon. Umumnya tanaman yang banyak dikembangkan di Cirebon adalah padi dan palawija. Akan tetapi komoditas tersebut belum mampu memberikan nilai ekonomis tinggi bagi warga sekitar. Untuk mensinergiskan program pertanian dan parowisata, maka pengembangan buah naga di Cirebon dilakukan untuk mendukung program Agrowisata Cirebon.

\section{METODE PELAKSANAAN}

Kegiatan PPMD dilakukan di Kelurahan Kalijaga, Kecamatan Harjamukti, Kota Cirebon, Jawa Barat. metode yang digunakan dalam kegiatan ini adalah dengan cara mengadakan penyuluhan yang bertempatkan di Kantor Kelurahan Kalijaga. Kegiatan penyuluhan terdiri dari sambutan pihak desa dan Universitas Padjadjaran, penyampaian materi, dan membuka forum diskusi. Jumlah peserta yang mengikuti kegiatan PPMD ini mencapai 126 peserta.

Peserta penyuluhan akan diberikan lembaran kuisioner yang berisi pertanyaan PreTest dan Post-Test. Pertanyaan pre-test dikerjakan sebelum penyampaian materi untuk mengukur wawasan peserta mengenai tanaman buah naga, serta budidaya tanaman buah naga, sedangkan pertanyaan post-test dikerjakan setelah penyampaian materi untuk mengukur tingkat ketertarikan peserta pada budidaya tanaman buah naga. Kuisioner pada saat pre-test terdiri dari 6 soal, yaitu: 1) Pengetahuan peserta mengenai tanaman buah naga; 2) Pengalaman peserta dalam mengonsumsi buah naga; 3) Pengalaman peserta dalam kegiatan budaya tanaman buah naga; 4) Ketertarikan perta dam budidaya buah naga; 5) Pengetahuan peserta dalam cara budidaya tanaman buah naga; 6) Pendapat peserta mengenai keuntungan dalam budidaya buah naga.

Kuisioner post-test terdiri dari 8 soal, yaitu: 1) Pendapat warga desa mengenai kecocokan untuk budidaya tanaman buah naga di desa ini; 2) Ketertarikan warga desa untuk mengembangkan budidaya tanaman buah naga lebih luas hingga skala pemasaran; 3) Pendapat warga desa mengenai kecocokan fasilitas yang tersedia di desa untuk budidaya tanaman buah naga; 4) Pendapat warga desa mengenai tingkat kesulitan untuk budidaya tanaman buah naga; 5) Kemampuan finansial warga dalam memulai usaha budidaya tanaman buah naga; 6) Pendapat warga desa mengenai potensi budidaya tanaman buah naga untuk meningkatkan perekonomian warga setelah mendapat materi penyuluhan;7) Kesediaan warga untuk bekerja sama dalam budidaya tanaman buah naga yang dapat menghasilkan secara berkelanjutan; 8) Kesediaan warga untuk memanfaatkan lahan yang dimiliki untuk budidaya tanaman buah naga. 


\section{HASIL DAN PEMBAHASAN}

Buah naga merupakan salah jenis tanaman buah-buahan yang sedang berkembang. Selain dikonsumsi sebagai. Buah segar, buah nga banyak dipergunakan untuk olahan pangan seperti cake, manisan, selai dll (Herianto, Hamzah, \& Yusmarini, 2015; Wahyuni, 2011). Selain untuk mahakan, banyak lagi manfaat dari buah naga diantaranta adalah untuk menurunkan gula darah, keputihan, mencegah bau mulut (Nugroho, 2011). Selain itu, buah naga memiliki nilai ekonomi yang cukup tinggi.

Budidaya buah naga memiliki peluang usaha yang cukup besar. Akan tetapi, banyak masyarakat di Indonesia terutama daerah yang terpencil yang belum mengenal tanaman buah naga serta cara untuk budidaya tanaman buah naga. Oleh karena itu, pengetahuan mengenai buah naga perlu di sebarluaskan kepada masyarakat, yang salah satunya adalah penyebaran informasi kepada masyarakat di Kelurahan Kalijaga, Kecamatan Harjamukti, Kota Cirebon (Gambar 1).

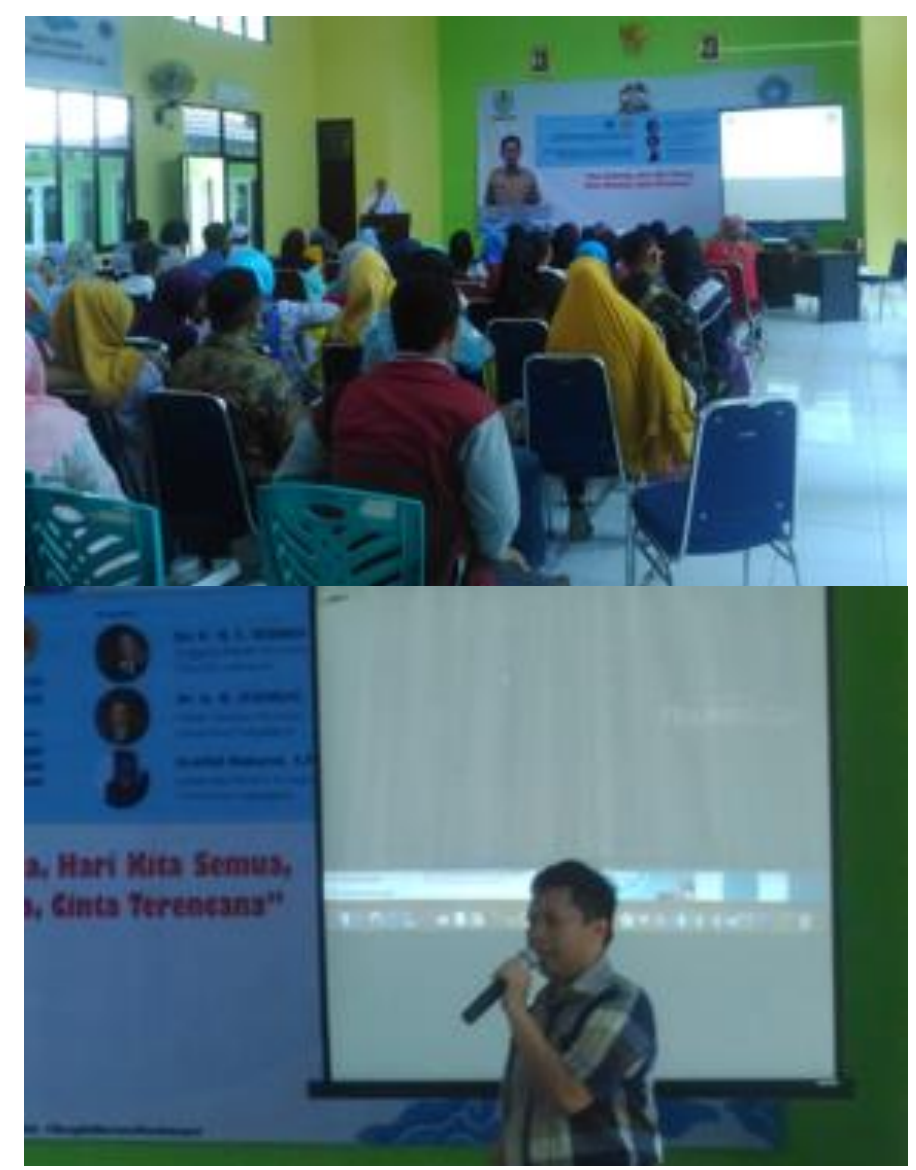

Gambar 1. Sosialisasi Budidaya Buah Naga di Kelurahan Kalijaga, Harjamukti, Kota Cirebon

Berdasarkan data dari hasil pre-test (Gambar 2) dengan jumlah responden sebanyak 126 peserta penyuluhan menunjukan bahwa hampir seluruh peserta penyuluhan mengetahui tanaman buah naga dan hanya sekitar $23 \%$ peserta yang belum mengehui tanaman buah naga. Dari hasil tersebut menunjukan bahwa mayoritas warga masyarakat di Cirebon telah mengetahui tanaman buah naga. Hal ini dapat dipahami karena perkembangan dan penyebaran buah naga telah menyebar luas dengan pesat di tanah air ini. Selain mengetahui tanaman buah naga, mayoritas dari warga masyrakat Cirebon pernah mengkonsumsi buah naga. Hal ini dibuktikan oleh hasil kuisioner yang 
menunjukan bahwa sekitar $86 \%$ peserta penyuluhan pernah mengkonsumsi buah naga dan hanya $14 \%$ peserta yang belum pernah mengkonsumsi buah naga.

Hampir seluruh peserta penyuluhan tidak memiliki pengalaman dalam budidaya tanaman buah naga yang ditunjukan oleh hasil kuisioner bahwa sekitar 95\% peserta penyuluhan belum berpengalaman dala budidaya tanaman buah naga. Akan tetapi, para peserta memiliki rasa ketertarikan yang tinggi dalam mengenal dan mempelajari budidaya tanaman buah naga. Hal in ditunjukan pada hasil kuisioner bahwa sekitar $88 \%$ peserta penyuluhan tertarik dalam budidaya tanaman buah naga.

Mayoritas masyarakat warga Cirebon belum mengetahui cara untuk budidaya tanaman buah naga dan masih menduga bahwa tanaman buah naga adalah tanaman yang tidak cocok ditanam di daerah Cirebon serta memerlukan lahan yang subur karena kondisi lingkungan yang cukup panas dan gersang. Hal ini ditunjukan dengan hasil kuisioner bahwa sekitar $94 \%$ peserta penyuluhan tidak mengetahui cara budidaya buah naga serta dari pertanyaan peserta pada saat acara berlangsung.

Menurut mayoritas peserta penyuluhan, budidaya tanaman buah naga menguntungkan bagi masyarakat dan dapat meningkatkan perekonomian warga masyarakat serta kota Cirebon. Hal ini ditunjukan oleh hasi kuisioner bahwa $84 \%$ dari peserta penyuluhan berpendapat budidaya tanaman buah naga menguntungkan bagi mereka dan hanya $16 \%$ peserta penyuluhan yang berpendapat budidaya tanaman buah naga kurang menguntungkan.

Secara umum, berdasarkan data hasil kuisioner sebelum pelaksanaan penyuluhan (pre-test) maka disimpulkan bahwa kegiatan penyuluhan yang dilakukan di Desa Kalijaga menunjukan bahwa hampir seluruh peserta penyuluhan memperlihatkan keterterikan untuk budidaya tanaman buah naga dan memiliki semangat serta antusiasme yang tinggi untuk budidaya dan mengembangkan tanaman buah naga di sekitar mereka. Ketertarikan dan antusias warga akan buah naga sangatlah bagus, hal ini dapat terlihat juga dari kegiatan yang dilakukan di Desa Cintararu, Kecamatan Parigi Kab. Pangandaran (Sudarjat, Isnaniawardhani, Qanit, \& Mubarok, 2017).

A

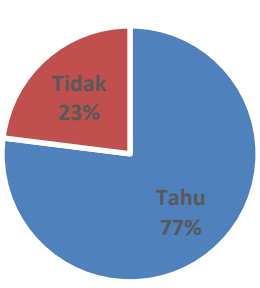

D

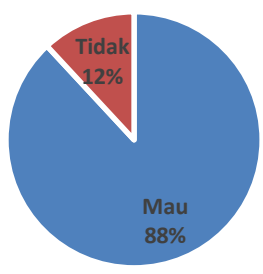

B

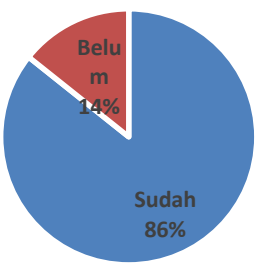

E

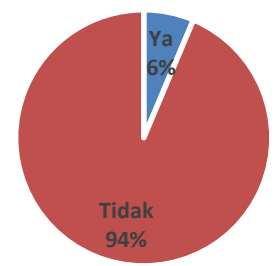

C

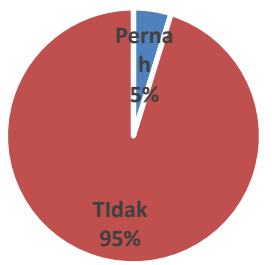

F

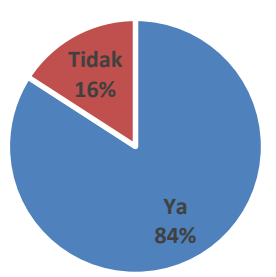

Gambar 2. Diagram Hasil Pre-Test Kegiatan Sosialisasi dan Penyuluhan Budidaya Buah Naga 
Tahap selanjutnya dari kegiatan ini adalah kegiatan penyampaian materi. Kegiatan ini dilakukan untuk meningkatkan wawasan peserta mengenai fungsi dan manfaat buah naga untuk kesehatan serta memberikan penjelasan mengenai keuntungan dalam budidaya buah naga yang dapat meningkatkan taraf hidup secara ekonomi. Peningkatan taraf hidup salah satunya dapat dilakukan dengan memanfaatkan dan membudidayakan tanaman buah naga dengan baik sesuai SOP budidaya tanaman buah naga yang benar, sehingga akan menghasilkan produk dengan kualitas hasil yang optimal. Peningkatan wawasan tentang teknologi budidaya yang baik dilakukan dengan menyampaikan materi di depan para peserta penyuluhan yang nantinya diharapkan peserta dapat menyebarkan informasi ke seluruh warga lain di desanya, sehingga informasi yang diperoleh dapat disebarkan dengan baik kepada warga yang tidak mendapat penyuluhan.

Pada akhir acara penyuluhan dilakukan evaluasi (post-test) berupa kuisioner yang bertujuan untuk melihat bagaimana respon peserta penyuluhan dan antusias masyarakat terhadap kegiatan penyuluhan yang sudah dilakukan (Gambar 3).

Berdasarkan total 126 peserta penyuluhan, hampir seluruh peserta memiliki rasa ketertarikan dalam melakukan budidaya tanaman buah naga lebih lanjut hingga mencapai skala pemasaran serta mulai percaya bahwa tanaman buah naga dapat ditanam di desa ini. Hal ini ditunjukan pada hasil kuisioner bahwa sebanyak $83 \%$ peserta penyuluhan merasa tertarik untuk melakukan budidaya tanaman buah naga hingga mencapai skala pemasaran dan sebanyak $86 \%$ peserta penyuluhan percaya bahwa tanaman buah naga cocok dibudidayakan di desa ini.

A
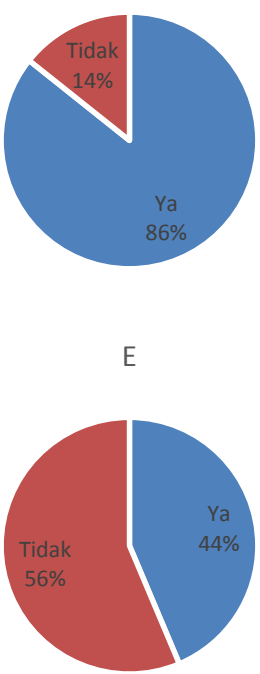

B
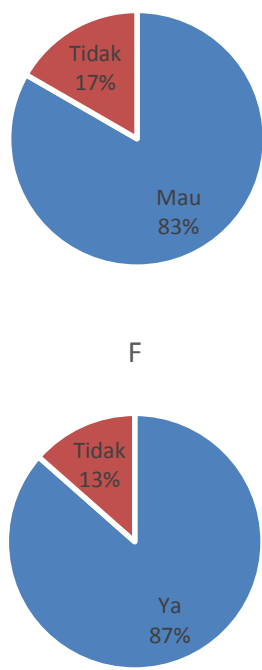

C

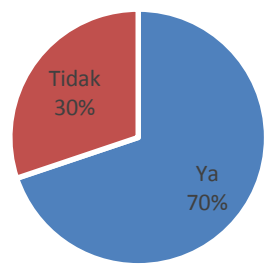

G

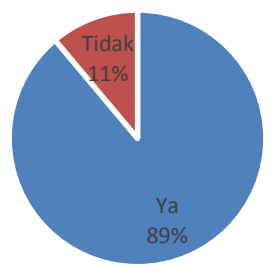

D

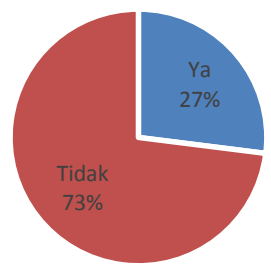

$\mathrm{H}$

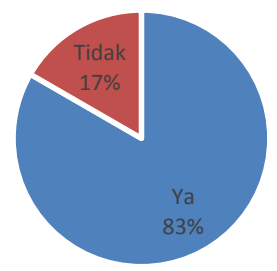

Gambar 3. Diagram Hasil Post-Test Kegiatan Sosialisasi dan Penyuluhan Budidaya Buah Naga

Setelah kegiatan penyuluhan ini, warga desa mulai sadar akan fasilitas yang tersedia di desa ini berpotensi dan mendukung dalam melakukan kegiatan budidaya buah naga serta sebagian besar warga beranggapan budidaya buah naga tidak terlalu sulit. Hal ini ditunjukan pada hasil kuisioner bahwa sekitar $70 \%$ peserta penyuluhan beranggapan bahwa fasilitas yang terdapat di desa ini berpotensi untuk mendukung kegiatan budidaya buah naga dan sebanyak $73 \%$ peserta penyuluhan yang beranggapan budidaya tanaman buah naga tidak terlalu sulit. Hanya sajai, hampir sebagian peserta penyuluhan beranggapan bahwa budidaya buah naga memerlukan biaya yang cukup besar yang 
ditunjukan pada hasil kuisioner terdapat $44 \%$ peserta penyuluhan yang berpendapat seperti itu. Meskipun begitu, hampir keseluruhan atau sebanyak $87 \%$ peserta penyuluhan yang berpendapat bahwa budidaya tanaman buah naga dapat menguntungkan dan meningkatkan taraf hidup warga. Dari 126 responden, terdapat $89 \%$ responden yang bersedia untuk bekerja sama untuk mengembangkan budidaya tanaman buah naga yang dapat menghasilkan secara berkelanjutan dan sebanyak $83 \%$ responden yang bersedia untuk menggunakan lahan mereka sebagai lahan untuk budidaya tanaman buah naga.

\section{SIMPULAN}

Program sosialisasi budidaya buah naga di Desa Kalijaga telah berhasil menginformasikan pentingnya tanaman buah naga untuk dikembangkan di daerah ini yang dapat digunakan sebagai tanaman bergizi sekaligus memotivasi para petani khususnya tokoh-tokoh kelompok tani untuk mencoba menanam tanaman buah naga. Antusias warga sangat tinggi untuk pengembangan buah naga di desa ini karena potensi dan kondisi lingkungan yang sesuai dengan syarat tumbuh buah naga. Selain itu sektor pariwisata di desa ini dapat mendukung terciptanya sektor pariwisata baru ke arah agrowisata buah naga.

Untuk mengoptimalisasi capaian terciptanya sektor pariwisata baru ke arah agrowisata buah naga, maka perlu dilakukan pengujian lebih lanjut untuk penentuan jenis buah naga apa yang cocok ditanam di Desa Kalijaga, Kecamatan Harjamukti, Kota Cirebon. Selain itu, perlu dilakukan pendampingan tentang tata cara budidaya yang benar dan sesuai dengan SOP budidaya buah naga.

\section{REFERENSI}

Chusna, C. B. (2011). Peluang bisnis buah naga di Indonesia. Yogyakarta: Universitas AMIKOM Yogyakarta.

Herianto, A., \& Hamzah, F., \& Yusmarini. (2015). Studi pemanfaatan buah pisang mas (Musa Acuminata) dan buah naga merah (Hylocereus Polyrhizus) dalam pembuatan selai. Jurnal Online Mahasiswa (JOM) FAPERTA, 2(2), 1-12.

Kasih, E. A. (2016). Profil kabupaten Pangandaran, Daerah otonomi baru yang penuh potensi. Retrieved August 29, 2017, from Eri Anggoro Kasih website: http://www.erianggorokasih.com/2016/12/profil-kabupaten-pangandarandaerah.html.

KKNM Unpad. (2017). Desa Cintaratu. Retrieved August 29, 2017, from Berita KKNM Unpad website: http://kknm.unpad.ac.id/cintaratu/

Kristanto, D. (2010). Buah naga, Pembudidayaan di pot dan di kebun. Cetakan IV (Edisi revisi). Jakarta: Penebar Swadaya.

Kristriandiny, O., \& Susanto, S. (2017). Budi daya buah naga putih (Hylocereus undatus) di Sleman, Yogyakarta: Panen dan pascapanen. Buletin Agrohorti, 4(1), 1-8. 
Sudarjat, Isnaniawardhani, V., Qanit, M. A. H., Mubarok, S. (2017). Sosialisasi budidaya buah naga untuk daerah pesisir di desa cintaratu, parigi, kabupaten pangandaran. Jurnal Pengabdian Pada Masyarakat, 2(2), 141-148.

Wahyuni, R. (2011). Optimasi pengolahan kembang gula jelly campuran kulit dan daging buah naga super merah (Hylocereus costaricensis) dan prakiraan biaya produksi. Teknologi Pangan, 1(1), 1-8. 